\title{
A SHIFT OF CELLULAR CALCIUM TO A MORE SLOWLY EXCHANGEABLE FRACTION DURING CONTRACTION IN GUINEA PIG TAENIA COLI
}

\author{
Hidcaki KARAKI and Norimoto URAKAWA \\ Deparment of Veterinary Pharmacology, Faculty of Agriculture. \\ University of Tokyo, Bunkyo-ku, Tokyo, Japan \\ Recuived for publication December 22, 1971
}

It is now generally agreed that $\mathrm{Ca}$ ion is essential for the contraction of smooth musele. On the role of $\mathrm{Ca}$ ion in the cuntraction cycle of smooth muscle, many electrophysiological studies have suggested that the action potential of the muscle cell is associated with an inward movement of $\mathrm{Ca}$ ions from anionic sites of cell menbrane or from extracelitular space and this $\mathrm{Ca}$ flow maly initiate contractile response $(1,2)$. It has also been suggested from radioisotope studies (3-6) that contraction in smooth muscle maly be triggered and mainlained by release of cellular $\mathrm{Ca}$ and $\mathrm{or}$ by influx of extracelluar $\mathrm{Ca}$.

Although Ca ions activating contractile protein of smooth muscle are said to be inactivated and stored in the cell until expelled (7). the ncehanism is sill obscure. In previous experiments, lissue Ca of taenia coli was tentatively divided into two fractions; a fraction which exchanges within 4 min and another fraction which is exchinguable but does not cxchange within 4 min, the latler more slowly exchangeable fraction was named as 'tightly bound fraction" (TBF) (4). The size of TBF increased during lonic contraction induced by carbachol, pilocarpine (3), histamine (4), barium (5) and $40 \mathrm{mM}$ potassium $(5,6)$, and decreased during abolition of tension by specilic antagonists of the stimulants $(3,4)$, metabolic inhibiting factors and factors inhibiting active Na transport (8, 9). From these dala, it was suggested that the increase in the sire of TBI, i.e., a shilt of celfular Ca to a more slowly exchangeable fraction, could be related to contraction of smooth muscle, and the movement of Cal related to metabolism.

In the experiment reported here, the eftect of external phosphate on the slowly exchanging Ca fraction, the change in the fraction in the course of muscle contraction and relaxalion and exclange kinetics of the fraction were studied to clarify the nature of the shift of cellular Ca to a more slowly cxchanging fraction in smooth muscle of taenia coli and the role of this $\mathrm{Ca}$ movement in excitation-contraction coupling in smooth muscle.

METHODS

Strips of taenia coli were isolated from male Hartley strain guinea pigs weighing about $500 \mathrm{~g}$. Tyrode solution containing $\mathrm{NaCl} 136.8, \mathrm{KCl} 2.7, \mathrm{CaCl}_{2} 2.5, \mathrm{MgCl}_{2} 1.0, \mathrm{NaH}_{2} \mathrm{PO}_{4}$ $0.4 \mathrm{NaHCO}_{3} 11.9$ and glucose $5.5 \mathrm{mM}$ was bubbled with $95 \% \mathrm{O}_{2}$ and $5 \% \mathrm{CO}_{2}$ mixture 
at $37 \mathrm{C}$. Tension changes were recorded isometrically. Tissue $\mathrm{Ca}$ and extracellular ${ }^{14} \mathrm{C}$ sorbitol space were determined as deseribed previously $(5,8)$.

For ${ }^{15} \mathrm{Ca}$ emux experiments, muscle strips were allowed to take up ${ }^{45} \mathrm{Ca}$ for at least $30 \mathrm{~min}$ in Tyrode solution without or with hypertonically added $40 \mathrm{mM} \mathrm{K}$ or $5.4 \times 10^{-65} \mathrm{M}$ histanine. Previous studies have shown that most of the tissue $\mathrm{Ca}$ in taenia coli was exchangeable and exchanged within 15 to $30 \mathrm{~min}(4,5,10)$. The more slowly exchanging fraction also increased 15 to $30 \mathrm{~min}$ after addition of the stimulants (4-6). After incubation, the muscle strips were washed with nonradioactive Tyrode solution, this being the same chemical composition as the incubation medium. In the first series of experiments the strips were removed from the bath after $2,4,6,8$ or 15 min wash period and radioactivity remaining in the strips was counted. The resultant "desaturation curve" was plotted on a uniform scale as $\mathrm{mEq} \mathrm{Ca} / \mathrm{Kg}$ wet tisste vs time after the start of wash (Fig. 3-A.). TBF corresponds to the value obtained after 4 min wash period in this experiment. In the next series of experiments the muscle strips were washed every min and the radioactivity in the strips during the efllux period was calculated from radioactivity in ench effuent and that remaining in the strips afior a 15 min wash period. The "ellux curve" obtained from this experiment was plotted on a semilogalithmic scale (Fig. 3-B). There was a slight difference in the curves showing initial faster exchange in the "desaturation curve" and the "efflux curve" which may be due to the fact that radjoactive solution adhering to muscle strips was carried with the strips into wast solution (11), and the curve showing initial faster exchange was not shown in the "eftlux curce" to avoid the uncertainty.

\section{RESULTS}

1. Effect of external phosphate an the size of $T B F$

When the external phosphate concentration was lowered from control level of $0.4 \mathrm{mM}$ to $0 \mathrm{mM}$, the size of $\mathrm{TBF}$ decreased from $1.70 \ldots 0.09 \mathrm{~nL} \mathrm{~g} / \mathrm{Kg}$ wet tissue (7) to $0.95 . \mathrm{t} 0.22$ $\mathrm{mEq} / \mathrm{Kg}(\delta)$ although tissue $\mathrm{Ca}$ did not chan e significantly (Fig. 1). Similar results have been reported by Schatzmann (12) and Goodford (13). In the presence of $40 \mathrm{mM} \mathrm{K}$, muscle strips contracted and both tissue $\mathrm{Ca}$ and TBF increased as reported previously $(5,6)$. Increments in the size in the presence of $40 \mathrm{mM} \mathrm{K}$ were scarcely affected by change in the external phosphate concentration (Fig. 1). Tension development by $40 \mathrm{mM} \mathrm{K}$ was also shown to be unaffected by external phosphate concentration (14).

A part of TBF which increased during contraction is termed as "accumulated Ca" for distinction, and the present results are summerized as; the "accumulated $\mathrm{Ca}$ " were not affected by the change in external phosphate concentration although a part of slowly exchangeable fraction was directly affected by the same factor.

\section{Change in "accumulated $\mathrm{Ca}$ " in the course of muscle contraction and relaxation}

The addition of $40 \mathrm{mM} \mathrm{K}$ to Tyrode solution bathing taenia coli resulted in a prompt rise of tension followed by a steady level which was maintained as long as the $\mathrm{K}$ concentration was elevated. During the tonic contraction "accumulated $\mathrm{Ca}$ " increased gradually. Tissue Ca also gradually increased during the period. When $40 \mathrm{mM} \mathrm{K}$ was washed out, 


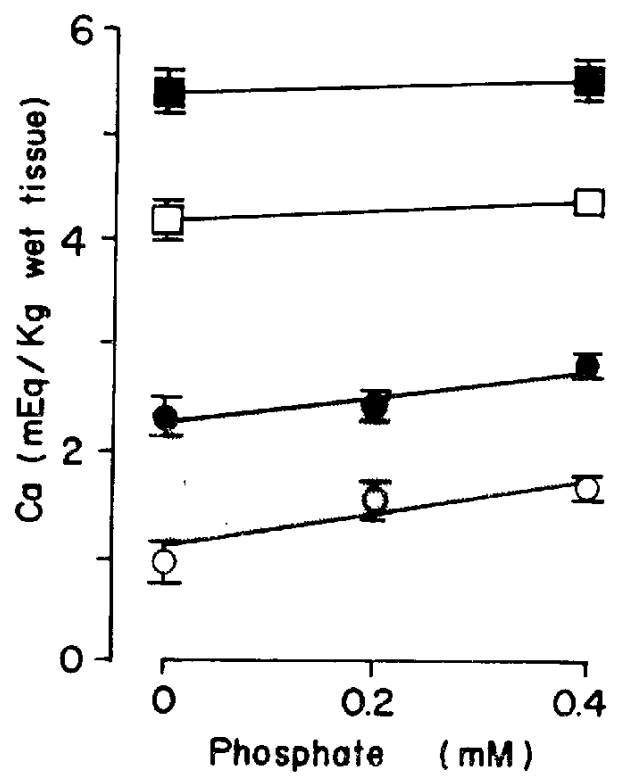

Fra. 1. Effect of phosphate concentration in the medium on tissuc $\mathrm{Ca}$ and $\mathrm{TBF}$ in guinea pig taenia coli.

Tissuc $\mathrm{Ca}$ (squares) was measured by atomic absorption spectrophotometer. TBF (circles) was determined as a Ca fraction which did not exchange within 4 min. Value in the absence (open symbols) and in the presence of hypertonically added $40 \mathrm{~m} \mathrm{M} \mathrm{K}$ (filled symbols) are shown. The difference between TBF in control lissue and that in $\mathrm{K}$-treated one, named as "accumulated Ca", wits nol attuted signifiantly by the change in phosphate concentration in the medium shaded area). Standard error of mean is shown by vertical line.

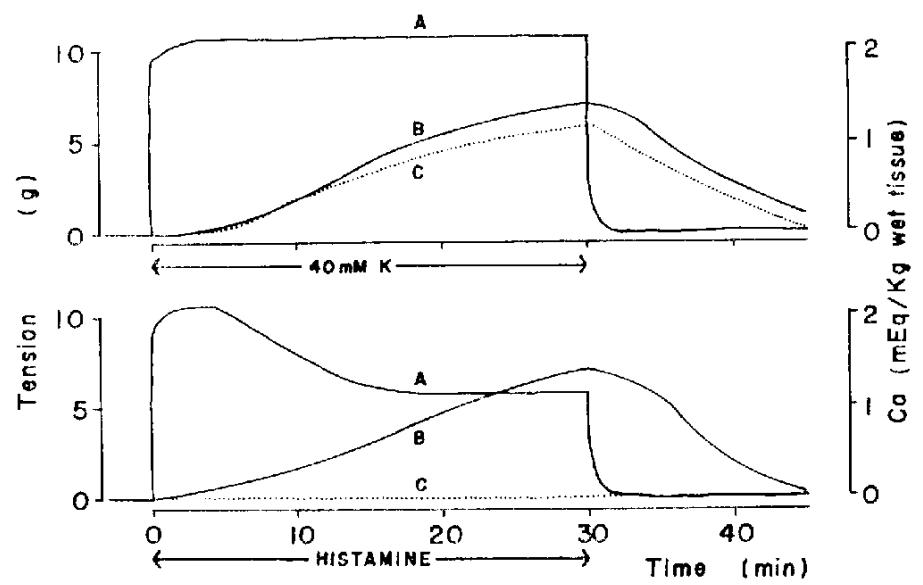

Iri. 2. Changes in tension, "accumulated $\mathrm{Ca}$ " and tissue $\mathrm{Ca}$ in the course of muscle contraction and relaxation in guinea pig taenia coil.

$\wedge$ : Tension change recorded isometrically.

$B$ : Change in "accumulated $\mathrm{Ca}$ " calculated from Table 1 as a difference between control TBF and that treated with $40 \mathrm{mM} \mathrm{K}$ or $5.4 \times 10^{-6} \mathrm{M}$ histamine.

C : Change in tissue Ca calulated from Table I similar to "accumulatedCa". 


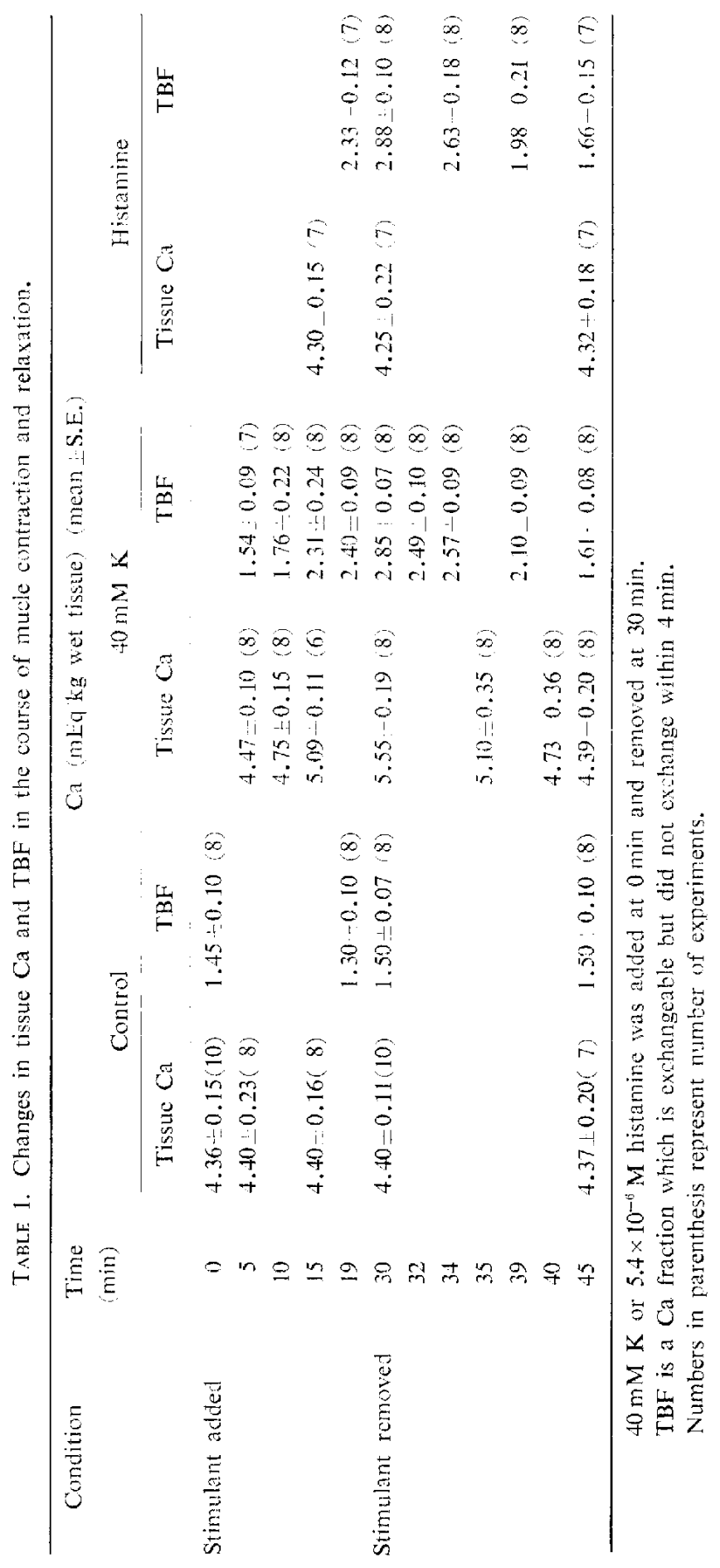


tension rapidly returned to the control level. However, approx. 15 min were required for both "accumulated $\mathrm{Ca}$ " and tissuc $\mathrm{Ca}$ to return to control levels. Similar results on "accumulated Ca" and tension were obtained using $5.4 \times 10^{-\mathrm{r}} \mathrm{M}$ histamine although tissue Ca remained unchanged in this case. These results ate shown in Table I and the changes in tension, "accumulated $\mathrm{Ca}$ " and tissue $\mathrm{Ca}$ are illustrated in Fig. 2.

Shimo and Holland (15) reported that the membrane depolarization induced by 40 $\mathrm{mM} \mathrm{K}$ returned to original level within few min after $40 \mathrm{mM} \mathrm{K}$ had been removed. The "accumulated Ca", however, remained still high at this time (Fig. 2). In the next experiments. a concentration of $K$ in the medium was elevated to $40 \mathrm{~m} . \mathrm{M}$ for $30 \mathrm{~min}$, then was lowered to control level. Two to three min later. $5.4 \cdot 10^{-6} \mathrm{M}$ histamine or $40 \mathrm{mM} \mathrm{K}$ was added. Tension development by $40 \mathrm{mM} \mathrm{K}$ did not change hut histamine induced only a small tension after the K-treatment.

These resulis show that $\mathrm{Ca}$ ions gradually accumulate in slowly exchanging fraction during contraction of the smooth muscle and slowly disperse after muscle relaxation. It is also suggested that "accumulated Ca" may not be a souree of Ca ions for muscle contraction but a depot for Ca which has been utilized for muscle contraction.

\section{Exchange kinctics of "actumbluted ca"}

In tacnia coli the cxchange kinetics of Ca cannot be fitted to a unique sum of first order processes $(5,11)$, hence the division of tissue $\mathrm{Ca}$ into fractions on this basis is unreliable. An attempled analysis of "Ca influx and efflux curves showed some apparent phases of $\mathrm{Ca}$ exchange in taenia coli $(10,11,16,17)$ although the phases may not invariably coincide with cellular $C$ a components $(2,5,11)$, In the following experiments an attempt was made to find the exchange kinctics of "accumulated Ca" from "Cal efllux experiments. The results are expressed in "desaturation curve" (Fig. 3-A) and "efflux curve" (Fig. 3-B) (see Methods). As can be seen in the figures almost $95 \%$ of tissie $\mathrm{Ca}$ cxchanged within 15 min and the tentative analysis of "efflux curve" revealed that most of the tissue $\mathrm{Ca}$ exchanged following three phases; initial rapidly exchanging component, the sccond component with a half-time of approx. 2 min and the third component with a half-time of approx. 7

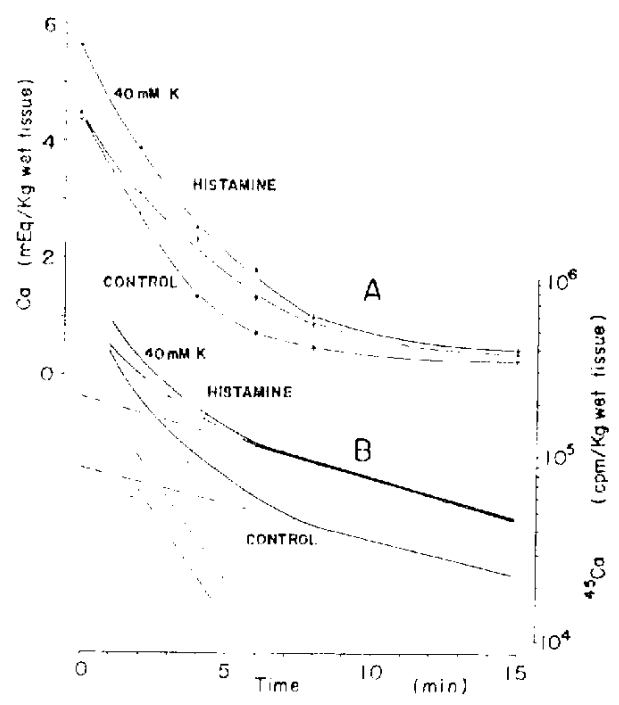

TIG. 3. Effect of $40 \mathrm{mM} \mathrm{K}$ and $5.4 \times 10^{-f} \mathrm{M}$ histamine on ${ }^{45} \mathrm{Ca}$ " desaturation curve" (upper) and "Ca "emlux curve" (lower) inguinea pig taenia coli.

Tissues were loaded in labeled Tyrode solution without or with $40 \mathrm{mM} \mathrm{K}$ or histamine for at least 30 min. Thereafter efflux went on in nonadioactive Tyrode solution of the same chemical composition as the incubation medium.

For further details, see text. 
min. When $5.4 \times 10^{-6} \mathrm{M}$ histamine was added to both ${ }^{45} \mathrm{Ca}$ incubation and wash solution, ${ }^{45} \mathrm{Ca}$ efflux was clearly slowed. The "desaturation curve" showed that significant differences between histamine-treated and those which served as control existed at the 4th and 6th min of eflux. The "efllux curve" also showed that the difference was mainly due to the decrease in the size of the second component and the increase in that of the third. In the presence of $40 \mathrm{mM} \mathrm{K},{ }^{45} \mathrm{Ca}$ uptake increased and the most of the extra ${ }^{15} \mathrm{Ca}$ in $40 \mathrm{mM}$ K-treated tissue was attributed to the increase in the third component.

These data suggest that a part of cellular $\mathrm{Ca}$, which exchanges with a half-time of approx. $7 \mathrm{~min}$, increases during contraction of taenia coli

\section{DISCUSSION}

The present experiments showed that a cellular $C$ a which exchanged with a half-time of approx. $7 \mathrm{~min}$ increased during tonic contraction in taenia coli and gradually decreased after muscle relaxation.

In longitudinal muscle strips of guinca pig small intestine Lüllmann and Siegfriedt $(18,19)$ reported that a $\mathrm{Ca}$ fraction with a half-time of 4 min decreased and that with a halftime of $22 \mathrm{~min}$ increased during contraction induced by $40 \mathrm{mM} \mathrm{K}$. They sugrested that the change in the relative size of the two cellular fractions in the presence of high potassium concentration is a result of a 1 ranser of Ca from a loosely bound fraction to a more firmly bound one. This data is compatible with the present one which exhibited a shift of $\mathrm{Ca}$ between the two fractions during contraction. In these experiments stimulants were added during both ${ }^{45} \mathrm{Ca}$ loading and effux perinds or only during the latter one. A similar result was obtained when the stimulants were added only in th: "Ca loading period. Van Breemen and Daniel (20) demonstrated a shift of $\mathrm{Ca}$ to a more slowly exchangeable fraction during contraction in the rat uterus by a slower effux of ${ }^{45} \mathrm{Ca}$ from uteri which were exposed to $191 \mathrm{mM} \mathrm{K}$ or acetylcholine during loading with "Ca than from the control uteri which were not stimulated during loading. The contraction of intestinal muscle by electrical stimulation (21) and of uterine muscle by $44 \mathrm{mM} \mathrm{K}$ (22) during " ${ }^{\circ} \mathrm{Ca}$ loading period also increased a residue of ${ }^{45} \mathrm{Ca}$ in the muscle after a wash period of the isotope. From these and the present data, it can be said that slowly exchanging (a ("accumulated Ca") increases during contraction in tacnia coli and also in other smooth muscle tissues.

Krejci and Daniel (22) suggested that contraction delayed ${ }^{25} \mathrm{Ca}$ fluxes due to the sequences of the mechanical events acompanying the contraction, e.g. changes in diffusion path through the extracellular space in rat uterine tissue. In taenia coli, however, ${ }^{45} \mathrm{Ca}$ fluxes were not slowed or even increased during contraction $(3,5,11,23)$, suggesting that the slowed ${ }^{56} \mathrm{Ca}$ movement observed in the present data is not the result of slowed diffusion of ${ }^{45} \mathrm{Ca}$ in the extracellular space.

The Ca accumulation during contraction in taenia coli has been postulated to be an active process depending on an aerobic carbolydrate breakdown and also related to an active $\mathrm{Na}$ transport $(8,9)$. Active $\mathrm{Ca}$ accumulation into some cellular fraction is necessary in order to maintain the ionic Ca concentration around contractile filaments at low level 
$(2,7,20)$. In skeletal muscle the endoplasmic reticulum is responsible for the active accumulation of Ca from the sarcoplasm to maintain muscle relaxation (24), however, the sarcoubular system is poorly developed in smooth muscle when compared to the elabolately organized structure fround in skelotal and cardiac muscles (25). As lor the Ca accumulating site in smooth muscle, Totsukat (26) demonstrated the ATP extrasplitting, "Ca binding and relaxing activities of microsomal fraction prepared from dog small intestine. Further, Kato et al. (27) showed electron microscopically that Ca slistributed in myofilament and natrix of mitochondria during contraction, and around pinocytolic vesicle and in cell interstitiun during relaxation of uterine muscle.

Goodford (7) has proposed that any (a entering the smooth muscle cell is rapidy removed, so long as sufficient metabolic energy is available, from the cytoplasm into storage site where it foms a microcrystalline precipitate of Ca phosphate whicl dissolves and liberates Ca slowly into the extracellular bathing solution and that the microcrystalline deposit may even be present in the absence of phosphate in the medium. In the present ditla a part of slowly exchanging (at fration but not the "accumulated Ca" decreasedwhen the external phosphate concentration was lowered. The "accumulated Ca" exchanged with a half-lime of approx. 7 min during contraction ( 1 ir. 3-3), wisich does not contradict the fact that the "accumulated" Ca" decreased to approx. 10", within 15 min alter muscle relaxation (Fig. 2). These observations suggest that the release of "accumulated Ca" might be unaffected by the changes associatled with mascle contraction or relaxation. The data secen to support the proposal of Gondtord (7) that (at accumulation is an active process while its release is inactive.

From the data, it is proposed that cyloplasmic Ca ion is continueusly supplied by $\mathrm{Ca}$ infux and or release of loosely bound membrane (at during tonie contation in laenia coli. The Ca ion which acted on contratite protein is actively and continuously accumulated in a slowly exchangeable (a fraction. The accumulated Ca disperses slowly into the extracellular solution. There is no evidence 10 suggest that the accumulated Ca is released agan into cytoplasm to induce contraction.

\section{SUMATARY}

A shift of cellular Ca to a nore slowly exchangeable fraction hats been found during Ionic contraction in guinea pig taenia coli. A part of the Ca fraction which incruased during contraction was termed as "accunulated $\mathrm{Ca}$ " atnd the nature of the Ca fraction was investigated.

1. Lowering the phosphate concentration in the external medium from control level of $0.4 \mathrm{mM}$ to $0 \mathrm{~mm}$ decreased a part of the slowly exchangeable fraction but not the "atcumulated Ca".

2. The addition of $40 \mathrm{mM} \mathrm{K}$ or $5.4 \cdot 10^{-4} \mathrm{M}$ histamine resulted in a prompt rise of tension followed by a new steady level which was maintained as long as the stimulant existed. During the tonic contraction the "accumulated Ca" increased gradually. When the stimulants were removed, muscle tension returned rapidly to the original level while 
almost 15 min was required for the "accumulated Ca" to attain the control level. It is suggested that the "accumulated $\mathrm{Ca}$ " is nol a source of $\mathrm{Ca}$ ion for muscle contraction but a depot of $\mathrm{Ca}$ which has been utilized for contraction.

3. From ${ }^{45} \mathrm{Ca}$ efflux experiments, the "accumulated $\mathrm{Ca}$ " was shown to exchange with a half-time of approx. 7 min.

4. From the data, it is proposed that the Ca ion acting on contractile protcin is actively and continuously accumulated in a slowly exchangeable Ca fraction during tonic contraction in laenia coli.

\section{REFERENCES}

1) Tomita, T.: Smooth Mascte, Luited by Bülbeivg, L. ct al., p. 197, Edward Arnold, London (1970)

2) Goodrord, P.J.: Smoot/ Muscte, Edited by Bülbrivg, E. ct al., p. 100, Edward Arnold, London (1970)

3) Nasl, T., Karaki, H. and Urakawa, N.: Jap. J. Pharmac. (10 be published)

4) Nasu, T., Karaki, H., Ikeda, M. and Urakawa, N.: Jap. J. Pharmac. 21, 597 (1971)

5) Karaki, H., Iktdda, N. and Urakawa, M.: Jap. J. Pharmac. 19, 201 (1969)

6) Urakawa, N. and holland, W.C.: Am. $J$. Physiol. 207, 873 (1964)

7) Goodford, P.J.: Muscle, Fdited by Paul, W.M. ct al., p. 219, Pergamon Press, London (1965)

8) Urakawa, N., Karak?, H. Avd Ikild, M.: Jap. J. Pintmar. 20, 360 (1970)

9) Karakt, H., IKLda, M. A\1) Ukakawa, N.: Jap. J. Pharmá. 20, 530 (1970)

10) Bauer, H., GoOdford, P.J. And Hiutek, J.: ./. Physiol. 176, 163 (1965)

11) Goodford, P.J.: J. Physiol. 176, 180)(1965)

12) Schatzmann, H.J.: Pharmacology of Smooth Mascle, Ldited by Bïlbrivic, E. al al, p. 57 , Perganon Press, Londen (1964)

13) GoOdFord, P.J.: J. Physiol. 192, 145 (1967)

14) Karaki, H., Urakawa, N. and IKeda, M,: Jap. I. Pharmac. 16, 423 (1966)

15) Shmo, Y. and Holland, W.C.: Am. J. Plysiol. 211, 1299 (1966)

16) Schatzmann, H.J.: Pflügers Arch. ges. Physiol. 274, 295 (1961)

17) Chumo, N. and Holinnd, W.C. Am. J. Physiol. 205, 94 (1963)

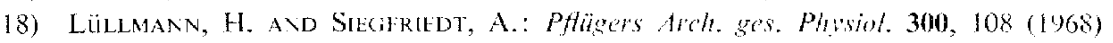

19) Lü̈rmane, 11.: Smooth Muscke, Edited by Bübring, L. et al., p. 151, Ldward Amold, London (1970)

20) Van Briemein, C. AND Danif., E.E.: J. gen. Physol. 49, 1299, (1906)

21) Lülmany, II. and Molis, P.: Pfligers Arch. ges. Physiol. 308, 214 (1969)

22) KRiJci, I. ANd DANILL, L.E.: Am. J. Physiol. 219, 256 (1970)

23) Bandidif, A.K. And Lewis, J.J.: J. Pharm. Pharmac. 15, 409 (1963)

24) Iluxı.FY, H.E.: Muscke, Edited by Paul, W.M. cl al., p. 3, Pergamen Press, London (1965)

25) Burnstock, G.: Smooth Mtrscke, Editud by Bulbrinci, L. et al., p. 100, Edward Anold, London (1970)

26) Tolsuks, M.: Sapporo Med. J. 28, 378 (1965) (in Jipontesc)

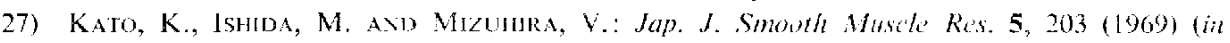
Japanese) 